\title{
Socio-Economic Impact of Little Millet Cultivation among Tribal Farmers
}

\author{
S. Vasanthapriya ${ }^{1}$, R. Premavathi ${ }^{1}$, T.R. Sridevi Krishnaveni ${ }^{1}$ and K. Qudsiya Jamal ${ }^{2}$ \\ ${ }^{1}$ Department of Agricultural Extension and Rural Sociology, TNAU, Coimbatore, India \\ ${ }^{2}$ Department of Agricultural Extension and Rural Sociology, AC\&RI, Madurai, India \\ *Corresponding author
}

\section{A B S T R A C T}

\begin{tabular}{|c|}
\hline Keywords \\
\hline $\begin{array}{l}\text { Socio-economic } \\
\text { impact, Little } \\
\text { millet, Tribes, } \\
\text { Tribal farmers. }\end{array}$ \\
\hline Article Info \\
\hline $\begin{array}{l}\text { Accepted: } \\
\text { 26 June } 2017 \\
\text { Available Online: } \\
\text { 10 August } 2017\end{array}$ \\
\hline
\end{tabular}

The Socio-Economic impact of little millet cultivation among tribal farmers in Tiruvannamalai district was selected purposively for this study since it is one among the districts where little millet is cultivated in more area by the tribal farmers. The Ex-post facto research design is taken for this study. Four villages viz., Kovilur, Veerappanur, Eriyur and Palamarathur from Jamunamarathur block of Tiruvannamalai district were chosen for conducting this research. The sample size consisted of 120 respondents selected from these villages by proportionate random sampling method. The findings of this study stated that the respondents had the increased changes in material (98.67\%), descendents $(56.67 \%)$ and economic $(57.92 \%)$ dimensions. No change was observed among majority of the respondents on farm (84.44\%) and social (66.00\%) dimensions.

\section{Introduction}

In the recent years concern for millets has been on the rise within Indian society and this has, together with substantive work done in the past, yielded a considerable body of evidence consisting of field experiences and academic literature from non-governmental and other sources showing the existence of valid linkages between millets, poverty reduction, malnutrition alleviation and rural development.

Millets provide food and livelihood security to millions of households, in particular, to small and marginal farmers and inhabitants of rainfed areas, especially in remote tribal areas. Millets are usually cultivated as dualpurpose crops providing both food grain for human consumption and straw for animals, contributing to economic efficiency in mixed farming systems. Millets are the staple crops in some rainfed regions (Dhan foundation, 2012).

Millets have been cultivated for around 3,000 years making them an integral part of the culture and history of India. References to millets can be found in mythology, poetry, religious practices, ayurvedic recipes, and in numerous dishes. Millets are not only food grains; they are still intricately interwoven in the socio-cultural fabric of numerous regions.

Millets are grown mainly under rain fed conditions in India. Many studies indicate that 
rainfed agriculture development in India will be the linchpin for inclusive growth of the nation, as large part of the poor rural households live in rainfed agriculture regions (World Bank, 2008).

\section{Materials and Methods}

Ex-post facto research design was used for this study.

Tiruvannamalai District was selected purposively for this study since it is one among the districts where little millet (samai) is cultivated in more area among tribal farmers.

Among 18 blocks, Jamunamarathur was selected based on maximum tribes' population. Four villages from this block were selected based on the maximum number of little millet cultivating tribal farmers. The selected villages were Kovilur, Palamarathur, Eriyur and Veerappanur of Jawadhu hills block.

The lists of little millet cultivating tribal farmers were obtained from the records of the Village Administrative Officers.

Proportionate random sampling procedure was employed in selecting 120 respondents from the selected four villages. The data were collected using a pre-tested interview schedule. The collected data were analysed and interpreted with cumulative frequency and percentage analysis.

\section{Results and Discussion}

\section{Overall socio-economic impact}

The overall socio-economic impact encountered by the respondents as a result of little millet cultivation was studied. Further the specific aspects of socio economic impact were also studied using a list of items under five sub heads. The overall socio-economic impact data are presented in table 1.

From the table 1, the respondents had the increased change in material (98.67\%), descendants' (56.67\%), and economic (57.92\%) dimensions. No change was observed among majority of the respondents on farm $(84.44 \%)$ and social $(66.00 \%)$ dimensions. The findings are in line with the results of Johnson (2002).

None of the respondents encountered decreased change under farm, material, descendants' and economic dimensions. A meager of 0.33 per cent of the respondents expressed decreased change in social dimension.

From the above findings it could be concluded that due to little millet cultivation many of the respondents increased their material status, descendent status and economic status due to maximum returns from little millet when compared with other cereals.

The overall analysis revealed that little millet cultivation has improved the status of the little millet cultivating tribal farmers.

\section{Specific socio-economic impact}

\section{Farm changes}

Among various farm changes observed, majority of the respondents felt increased change in purchase of additional livestock $(75.83 \%)$ followed by one-fourth $(25.00 \%)$ of the respondents felt increased change in purchase of new tools / equipments, improved the existing land $(20.83 \%)$ and purchase of new implement $(15.833 \%)$.

A meager level of respondents felt increased change in deepened the existing well and purchased new lands $(0.83 \%)$. 
Table.1 Overall socio-economic impact conceived by the respondents as result of little millet cultivation

$(\mathrm{n}=120)$

\begin{tabular}{|l|l|l|l|l|}
\hline S. No & \multirow{2}{*}{ Particulars } & \multicolumn{3}{|c|}{ Change indicators } \\
\cline { 3 - 5 } & & No change & Increased & Decreased \\
\hline 1. & Farm changes & 15.5556 & 84.4444 & 0.00 \\
\hline 2. & Material changes & 98.67 & 1.3333 & 0.00 \\
\hline 3. & descendants' changes & 56.67 & 43.3333 & 0.00 \\
\hline 4. & Economic changes & 57.92 & 42.0833 & 0.00 \\
\hline 5. & Social changes & 33.67 & 66.00 & 0.33 \\
\hline
\end{tabular}

Table. 2 Socio-economic impact perceived by the respondents as a result of little millet cultivation

$(\mathrm{n}=120)$

\begin{tabular}{|c|c|c|c|c|c|c|c|}
\hline \multirow[t]{2}{*}{ S. No } & \multirow{3}{*}{ Particulars } & \multicolumn{6}{|c|}{ Change indicators } \\
\hline & & \multicolumn{2}{|c|}{ Increased } & \multicolumn{2}{|c|}{ No change } & \multicolumn{2}{|c|}{ Decreased } \\
\hline A. Farm changes & & No & $\%$ & No & $\%$ & No & $\%$ \\
\hline a. & Purchased new lands & 1 & 0.833 & 119 & 99.167 & - & - \\
\hline b. & Improved the existing land & 25 & 20.83 & 95 & 79.167 & - & - \\
\hline c. & Leased in lands for cultivation & - & - & 120 & 100.00 & - & - \\
\hline d. & Leased out lands for cultivation & - & - & 120 & 100.00 & - & - \\
\hline e. & Deepened the existing well / bore wells & 2 & 1.667 & 118 & 98.33 & - & - \\
\hline f. & Dug new well / bore well & - & - & 120 & 100.00 & - & - \\
\hline g. & Purchased new implement & 19 & 15.833 & 101 & 84.167 & - & - \\
\hline h. & Purchased new tools / equipment & 30 & 25.00 & 90 & 75.00 & - & - \\
\hline i. & Purchased additional livestock & 91 & 75.833 & 29 & 24.167 & - & - \\
\hline \multicolumn{8}{|c|}{ B. Material change } \\
\hline a. & Purchased new utensils & 120 & 100.00 & - & - & - & - \\
\hline b. & Purchased household appliances & 117 & 97.50 & 3 & 2.50 & - & - \\
\hline c. & Purchased new jewels & 120 & 100.00 & - & - & - & - \\
\hline d. & Purchased new vehicle & 115 & 95.833 & 5 & 4.167 & - & - \\
\hline e. & Purchased TV, Radio, Phone, Tape, etc. & 120 & 100.00 & - & - & - & - \\
\hline \multicolumn{8}{|c|}{ C. descendants' change } \\
\hline a. & Provided higher education to children & 26 & 21.667 & 94 & 78.33 & - & - \\
\hline b. & Had better health care & 114 & 95.00 & 6 & 5.00 & - & - \\
\hline c. & Had better nutritious food & 120 & 100.00 & - & - & - & - \\
\hline d. & $\begin{array}{l}\text { Spent more for religious and other } \\
\text { activities }\end{array}$ & 23 & 19.167 & 97 & 80.33 & - & - \\
\hline e. & Spent more for food and clothing & 57 & 47.50 & 63 & 52.50 & - & - \\
\hline \multicolumn{8}{|c|}{ D. Economic change } \\
\hline a. & Repayment of loans & 71 & 59.167 & 49 & 40.833 & - & - \\
\hline b. & Increased savings and deposits & 68 & 56.667 & 52 & 43.33 & - & - \\
\hline \multicolumn{8}{|c|}{ E. Social change } \\
\hline a. & Extension contact & 35 & 29.167 & 85 & 70.833 & - & - \\
\hline b. & Organization participation & 83 & 69.167 & 37 & 30.833 & - & - \\
\hline c. & Opinion leader & 13 & 10.833 & 106 & 88.33 & 1 & 0.833 \\
\hline d. & Emerged as a leader & 14 & 11.667 & 105 & 87.5 & 1 & 0.833 \\
\hline e. & Increased outside contact & 57 & 47.50 & 63 & 52.50 & - & - \\
\hline
\end{tabular}

*Multiple responses obtained 
It is seen that all the respondents $(100.00 \%)$ felt no change due to little millet cultivation in indicators like leased in lands for cultivation, leased out land for cultivation and dug new well.

Only $24.17 \%$ of the respondents felt no change in purchase of additional livestock. Majority of the respondents felt no change in purchase of new lands (99.17\%), deepened the existing well $(98.33 \%)$, purchase of new implement $(84.17 \%)$, improved the existing land $(79.17 \%)$ and purchase of new tools / equipment $(75.00 \%)$ respectively.

\section{Material changes}

While analyzing the data on material change, cent per cent of respondents expressed that they purchased new utensils, purchased new jewels and purchased TV, radio, phone, tape, etc.

A vast majority $(97.50 \%)$ of the respondents purchased household appliances. More or less the same percentage $(95.83 \%)$ of the respondents purchased new vehicle.

A meager level of respondents felt no changes in purchase of new vehicle (4.17\%) and purchase of household appliances $(2.50 \%)$. The overall analysis showed that the increase in material changes was relatively more than other types of changes.

\section{Descendants' changes}

Under descendants changes all the respondents had better nutritious food. This was followed by 95.00 per cent of respondents who had better health care. Nearly half of the respondents $(47.50 \%)$ spent more for food and clothing. Less than one fourth of the respondents provided higher education to children $(21.67 \%)$ and spent for religious and other activities $(19.17 \%)$.

\section{Economic changes}

Under economic changes the repayment of loans and savings were observed. More than half of the respondents $(59.17 \%)$ repaid the loans. There were 56.67 per cent of respondents who invested the extra money gained due to little millet cultivation in savings and deposits. This result is contradictory with the findings derived by Balarubini (2015) (Table 2).

\section{Social changes}

More than half of the respondents $(69.17 \%)$ opined that their organizational participation was increased. Nearly half of the respondents $(47.50 \%)$ stated that they have increased their outside contact. Less than one-third of the respondents had increased extension contact $(29.17 \%)$. A very low level of respondents $(11.67 \%)$ emerged as a leader and 10.83 per cent of respondents only stated that they could gain the opinion leadership status.

\section{References}

Balarubini, M. 2015. A study on socio-economic impact of thane storm on cashew growers in Cuddalore district of Tamil Nadu. Unpub. M.Sc. (Ag) Thesis, TNAU, Coimbatore.

DHAN foundation, Report of Supporting millets in India: Policy Review and Suggestions for Action, 2012. can be retrieved from http://www.dhan.org/smallmillets/ docs/report/Millet_Support_Policies.pdf

Johnson, B. 2002. Socio-economic Impact of Cashew Cultivation and Marketing. Unpub. M.Sc. (Ag.) Thesis, TNAU, Coimbatore.

World Bank, Agriculture for Development: World Development Report, 2008.

\section{How to cite this article:}

Vasanthapriya, S., R. Premavathi, T.R. Sridevi Krishnaveni and Qudsiya Jamal, K. 2017. SocioEconomic Impact of Little Millet Cultivation among Tribal Farmers. Int.J.Curr.Microbiol.App.Sci. 6(8): 3172-3175. doi: https://doi.org/10.20546/ijcmas.2017.608.377 